\title{
THE ECONOMETRIC THEORY AWARDS 2021
}

I am delighted to announce the following Econometric Theory Awards for 2021.

\author{
Multa Scripsit (2021): Brendan K. Beare \\ David Harvey \\ Jonathan B. Hill \\ Wen-Jen Tsay
}

Plura Scripsit (2021): Jiti Gao

There are presently three levels of ET award: Multa Scripsit, Plura Scripsit, and Plurima Scripsit. The awards are made annually using an automated point system based on an author's cumulative publications in ET. A description of the award system and a copy of the ET Award Certificate may be viewed on the Econometric Theory website at https://www.cambridge.org/core/journals/econometric-theory/ et-awards.

Cambridge University Press joins me in congratulating the recipients of the 2021 ET Awards and thanking them for their sustained contributions to econometric theory.

Peter C. B. Phillips

February 2021 